\title{
ANALISIS OPTIMALISASI ASET MILIK PEMERINTAH PROVINSI SULAWESI UTARA (Studi Kasus Tanah Bekas Bangunan UPTD Metrologi di Jalan Sam Ratulangi Nomor 87 Manado)
}

\author{
Tulus GP Siahaan, Rosalina A.M.Koleangan, Daisy S.M. Engka \\ Fakultas Ekonomi dan Bisnis, Magister Ilmu Ekonomi \\ Universitas Sam Ratulangi, Manado
}

\begin{abstract}
ABSTRAK
Analisis Optimalisasi Aset Tanah Bekas Bangunan Unit Pelaksana Teknis Dinas (UPTD) Metrologi Provinsi Sulawesi Utara Milik Pemerintah Provinsi Sulawesi Utara menggunakan Analisis Highest And Best Use (HBU). Alat analisis yang digunakan adalah dilakukan dengan cara analisis produktifitas properti meliputi aspek fisik dan lokasi serta aspek hukum dan peraturan sehingga diperoleh alternatif penggunaan yang memungkinkan. Analisis selanjutnya adalah analisis pasar yaitu analisis permintaan, penawaran pasar, dan analisis kelayakan keuangan untuk setiap usulan penggunaan yaitu untuk hotel, pusat perbelanjaan dan hotel.

Dalam penelitian ini, data yang dianalisis terdiri dari data primer dan data sekunder. Data primer meliputi data pendapatan, sewa dan pengeluaran yang diajukan sebagai alternatif penggunaan, diperoleh dengan bentuk wawancara berstruktur, sedangkan data fisik yang meliputi ukuran, bentuk tapak, topografi, utilitas dan lain-lain diperoleh melalui observasi langsung. Data sekunder diperoleh dari BPKAD Provinsi Sulawesi Utara, Badan Pusat Statistik, Situs Media Online dan sumber-sumber lain yang berhubungan dengan penelitian ini.
\end{abstract}

Kata Kunci : Optimalisasi, Aset

ABSTRACT

Used Land Asset optimization analysis Ex Building Technical Implementation Unit (UPTD) Metrology North Sulawesi Province, Government-owned North Sulawesi Province by Using Analysis Highest And Best Use (HBU). The analysis tool used by the analysis of productivity and the physical aspects of the property include the location as well as the legal and regulatory aspects in order to obtain alternative uses which allows. Next step is about market analysis which is analyze market demand and supply, also financial feasibility study for every alternative, namely for the construction hotel, shopping center and parking of vehicles.

In this study, the data were analyzed consist of primary data and secondary data. Primary data includes data revenues, rents and expenditure proposed as an alternative to the use, obtained by structured interview form, while the physical data which includes the size, shape of the tread, topography, utilities and others obtained through direct observation. Secondary data available at government office such as BPKAD Provinsi Sulawesi Utara, Central Bureau of Statistics, Online Media and other sources related to this research.

Keywords : Optimization, Asset 


\section{PENDAHULUAN}

Undang-Undang Nomor 22 Tahun 1999 tentang Pemerintahan Daerah merupakan tonggak awal negara Indonesia menganut sistem pemerintahanyang bersifat desentralisasi atau yang lebih dikenal dengan otonomi daerah. Ketentuan Peraturan perundang-undangan Pemerintahan Daerah tersebut telah mengalami beberapa kali perubahan. Perubahan terakhir adalah Undang-Undang Nomor 2 Tahun 2015 yaitu Peraturan Pemerintah Pengganti Undang-Undang Nomor 2 Tahun 2014 tentang Perubahan Atas Undang-Undang Nomor 23 Tahun 2014 tentang Pemerintahan Daerah Menjadi Undang-Undang. Otonomi Daerah adalah hak, wewenang, dan kewajiban daerah otonom untuk mengatur dan mengurus sendiri urusan pemerintahan dan kepentingan masyarakat setempat dalam sistem Negara Kesatuan Republik Indonesia yang bertujuan untuk mempercepat terwujudnya kesejahteraan masyarakat melalui peningkatan pelayanan, pemberdayaan, dan peran serta masyarakat dengan berpedoman pada prinsip-prinsip sebagai berikut : (1) Otonomi seluas-luasnya, yakni pemerintah daerah diberikan kewenangan untuk mengurus dan mengatur semua urusan pemerintahan di daerah, kecuali urusan yang berkenaan dengan kewenangan Pemerintah Pusat, sebagaimana ketentuan pasal 10 ayat 3 Undang-undang Nomor 32 Tahun 2004; (2) Otonomi nyata, yakni pemerintahan dilaksanakan berdasarkan tugas, wewenang, dan kewajiban yang telah ada dan berkembang sesuai dengan potensi daerah masing-masing; (3) Otonomi bertanggung jawab, yakni penyelenggaraan otonomi harus benar-benar sejalan dengan tujuan dan maksud otonomi yang pada intinya adalah pemberdayaan daerah, termasuk meningkatkan kesejahteraan masyarakat.

Pelaksanaan otonomi daerah selain memberikan kebebasan untuk mengatur dan mengurus seluruh urusan pemerintahan di tingkat daerah, baik provinsi maupun kabupaten/kota. Otonomi daerah juga memberikan dampak terhadap keuangan daerah yang harus dikelola secara mandiri untuk dapat membiayai penyelenggaraan pemerintahan dan pembangunan daerah.

Salah satu sektor yang dapat diharapkan menjadi sumber pendapatan daerah adalah aset daerah dalam sektor pertanahan. Pemerintah daerah dituntut untuk mampu mengoptimalkan sumber-sumber Pendapatan Asli Daerah (PAD) yang berasal dari pajak daerah, retribusi daerah, pengelolaan kekayaan daerah yang dipisahkan, dan lain-lain PAD yang sah (Pasal 157 huruf (a) Undang-undang Nomor 32 tahun 2004).

Sektor pajak dan retribusi daerah diatur terpisah dalam Undang-undang Nomor 28 Tahun 2009 tentang Pajak Daerah dan Retribusi Daerah sesuai dengan amanat pasal 158 Undang-undang Nomor 32 tahun 2004, dengan ketentuan pelaksanaan teknisnya diatur dengan Peraturan Daerah. Hal ini berarti bahwa pemerintah daerah memiliki kewenangan penuh untuk mengoptimalkan Pendapatan Asli Daerahnya (PAD). Upaya optimalisasi tersebut termasuk penggalian potensi pemberdayaan aset yang dimiliki daerah sebagai pendapatan yang berasal dari retribusi daerah(ketentuan pasal 1 angka 64 jo. pasal 108 ayat (1) jo. pasal 126 Undang-Undang Nomor 28 Tahun 2009).

Setiap daerah dituntut untuk mampu mengurangi ketergantungannya pada pemerintah pusat. Olehnya itu, daerah-daerah dituntut untuk lebih kreatif dalam 
menunjang pembangunannya baik melalui peningkatan Pendapatan Asli Daerah (PAD) maupun efisiensi dalam mengalokasikan anggaran pembangunan dengan melibatkan partisipasi masyarakat secara langsung. Salah satu yang dapat dilakukan daerah adalah dengan melakukan pengelolaan aset secara optimal, sehingga aset barang milik daerah tersebut mampu memberikan nilai tambah seperti membuka lapangan kerja bagi masyarakat.

Pengelolaan aset daerah secara optimal, selain memberikan manfaat juga merupakan salah satu kunci keberhasilan pembangunan ekonomi. Pemanfaatan aset daerah pada dasarnya ditujukan agar tidak membebani APBD, khususnya terkait biaya pemeliharaan,kemungkinan adanya penyerobotan dari pihak lain yang tidak bertanggung jawab serta mendapat imbalan uang tunai yang tentunya dapat dijadikan salah satu sumber PAD. Praktek di lapangan menunjukkan bahwa pemerintah daerah sulit untuk melakukan pemanfaatan aset dikarenakan belum tertibnya pengelolaan aset yang dimiliki, sehingga selain banyak aset yang penggunaannya tidak optimal, pemerintah daerah juga akan mengalami kesulitan untuk mengembangkan pemanfaatan aset.Sering kali di suatu daerah memiliki potensi kekayaan yang melimpah namun karena tidak dikelola dengan baik, maka daerah tersebut seolaholah miskin dan tidak memiliki cukup pendapatan untuk mengelola dan mengembangkan daerahnya serta menjalankan pemerintahan. Oleh karena itu, dalam sistem otonomi daerah ini diperlukan upaya manajemen aset yang lebih baik dalam mewujudkan pemberdayaannya.

Aset milik pemerintah dapat berupa tanah, bangunan, peralatan dan mesin, jalan, irigasi dan saluran, konstruksi yang masih dalam tahap pengerjaan, dan beberapa aset lainnya. Namun saat ini masih saja terdapat aset milik pemerintah yang tidak terawat dan dibiarkan begitu saja, sehingga optimalisasi aset masih kurang.

Optimalisasi aset dapat dilakukan dengan dua cara, yaitu studi optimalisasi aset dan perantara investasi. Studi optimalisasi aset dapat dilakukan antara lain dengan identifikasi aset, pengembangan basis data aset, studi Highest and Best Use atas aset, dan pengembangan strategi optimalisasi aset (Siregar, 2004: 523).Highest and Best Use (HBU) didefinisikan sebagai kegunaan yang paling layak, memungkinkan, dan sah dari tanah kosong atau tanah terbangun yang secara fisik memungkinkan, tepat didukung, layak secara finansial, dan yang menghasilkan nilai tertinggi dari tanah.

Penelitian ini akan membahas Aset Tetap milik Pemerintah Provinsi Sulawesi Utara berupatanahbekas Bangunan Unit Pelaksana Teknis Dinas (UPTD) Metrologi Provinsi Sulawesi Utara seluas $2.644 \mathrm{~m}^{2}$ yang terletak di Jalan Sam Ratulangi Nomor 87, Kelurahan Wenang Utara, Kecamatan Manado Selatan, Kota Manado.

\section{Teori Aset}

\section{LANDASAN TEORI}

Aset adalah sesuatu atau barang yang dimiliki oleh seseorang, badan usaha, atau instansi, yang memiliki nilai ekonomi, nilai komersial dan nilai tukar, di mana aset tersebut dapat berupa barang tidak bergerak (tanah dan bangunan) atau barang bergerak (modal, simpanan, hutang) yang dapat dianggap sebagai harta kekayaan (Siregar, 2004: 178). 
Menurut Standar Akuntansi Pemerintah (SAP) aset adalah sumber daya yang dapat memberikan manfaat ekonomi dan/atau sosial yang dikuasai dan/atau dimiliki oleh Pemerintah, dan dapat diukur dalam satuan uang, termasuk didalamnya sumber daya non keuangan yang diperlukan untuk penyediaan jasa bagi masyarakat umum dan sumber-sumber daya yang dipelihara karena alasan sejarah dan budaya. Aset berupa tanah menurut SAP merupakan aset tetap yaitu adalah aset berwujud yang mempunyai masa manfaat lebih dari 12 (dua belas) bulan untuk digunakan dalam kegiatan pemerintah atau dimanfaatkan oleh masyarakat umum. Tanah yang dikelompokkan sebagai aset tetap ialah tanah yang diperoleh dengan maksud untuk dipakai dalam kegiatan operasional pemerintah dan dalam kondisi siap dipakai.

Pengakuan Tanah Kepemilikan atas Tanah ditunjukkan dengan adanya bukti bahwa telah terjadi perpindahan hak kepemilikan dan/atau penguasaan secara hukum seperti sertifikat tanah. Apabila perolehan tanah belum didukung dengan bukti secara hukum maka tanah tersebut harus diakui pada saat terdapat bukti bahwa penguasaannya telah berpindah, misalnya telah terjadi pembayaran dan penguasaan atas sertifikat tanah atas nama pemilik sebelumnya.

\section{Pengertian Optimalisasi Aset}

Menurut Kamus Besar Bahasa Indonesia (2008:986), “Optimalisasi adalah proses, cara dan perbuatan untuk mengoptimalkan (menjadikan paling baik, paling tinggi)".Jadi,Optimalisasi adalah sebuah proses, cara dan perbuatan (aktivitas/kegiatan) untuk mencari solusi terbaik dalam beberapa masalah, dimana yang terbaik sesuai dengan kriteria tertentu. Dalam penelitian ini, topik yang diangkat adalah optimalisasi suatuaset sehingga dapat meningkatkan produktivitas dan pendapatan dari aset tersebut.

Optimalisasi aset merupakan proses kerja dalam manajemen aset yang bertujuan untuk mengoptimalkan potensi fisik, lokasi, nilai, jumlah/volume, legal, dan ekonomi yang dimiliki aset tersebut, Sutrisno (2004). Pada tahap ini aset-aset yang dimiliki negara diidentifikasi dan dikelompokkan berdasarkan potensi dari aset tersebut. Sedangkan menurut Nugent (2010) optimizing the utilization of asset is terms of service benefit and financial returns. Optimalisasi pemanfaatan aset adalah hubungan antara kegunaan layanan dan imbalan keuntungan. Dari pernyataan tersebut dapat disimpulkan bahwa optimalisasi aset merupakan pengoptimalan pemanfaatan dari sebuah aset dimana dapat menghasilkan manfaat yang lebih atau juga mendatangkan pendapatan.

Analisis optimalisasi penggunaan dan pemanfaatan aset digunakan untuk mengidentifikasi dan memilah aset yang masuk ke dalam aset operasional atau aset non operasional (Siregar, 2004). Untuk aset operasional, dilakukan kajian yang lebih mendalam untuk mengetahui apakah aset operasional tersebut sudah optimal atau belum penggunaan dan pemanfaatannya. Sedangkan untuk analisis terhadap aset non operasional yang dilakukan terhadap kondisi eksisting suatu aset. Untuk mengetahui pemanfaatannya sudah optimal, dilihat dari penggunaan aset dari aspek ekonomis. Sebagaimana disebutkan oleh Siregar (2004) bahwa untuk mengoptimalkan suatu aset harus dibuat sebuah formulasi strategi untuk meminimalisasi dan menghilangkan 
ancaman dari faktor lingkungan dan untuk aset yang tidak dapat dioptimalkan harus dicari penyebabnya.

Menurut Siregar (2004) bahwa optimalisasi pengelolaan aset itu harus memaksimalkan ketersediaan aset (maximize asset availability), memaksimalkan penggunaan aset (maximize asset utilization), dan meminimalkan biaya kepemilikan (minimize cost of ownership). Untuk mengoptimakan suatu aset dapat dilakukan melalui Highest and Best Use Analysis, Siregar (2004). Hal ini dapat dilakukan dengan meminimalisasi atau menghilangkan hambatan atau ancaman atas pengelolaan aset-aset tersebut. Sehingga optimalisasi dari suatu aset yang berstatus idle capacity bisa dilakukan.

\section{Tujuan Optimalisasi Aset}

Siregar (2004:776), menyebutkan bahwa tujuan optimalisasi aset secara umum adalah sebagaimana berikut :

1) Mengidentifikasi dan menginventarisasi semua aset. Kegiatan ini meliputi bentuk, ukuran, fisik, legal, sekaligus mengetahui nilai pasar atas masing-masing aset tersebut yang mencerminkan manfaat ekonominya.

2) Pemanfaatan aset. Pada tahap ini pengelola aset harus mengetahaui apakah aset telah sesuai dengan peruntukannya atau tidak.

3) Terciptanya suatu sistem informasi dan administrasi sehingga tercapainya efisiensi dan efektifitas dalam pengelolaan aset.

Sehingga dapat disimpulkan bahwa optimalisasi aset bertujuan untuk mengidentifikasi aset, untuk mengetahui aset yang perlu dioptimalkan dan bagaimana cara mengoptimalkan aset tersebut. Pada akhirnya diperoleh rekomendasi yang berupa sasaran, strategi, dan program untuk mengoptimalkan aset yang diteliti.

\section{METODE PENELITIAN}

\section{Metode Analisis Data}

Metode analisis data yang digunakan dalam penelitian ini adalah analisis data kualitatif dilakukan secara induktif, yaitu penelitian kualitatif tidak dimulai dari deduksi teori tetapi dimulai dari fakta empiris. Penelitian dilakukan langsung ke objek penelitian, mempelajari, menganalisis dan menarik kesimpulan dari fenomena yang ada di lapangan. Analisis data dilakukan dilakukan dengan menggunakan analisis Penggunaan Tertinggi dan Terbaik (Highest and Best Use) dengan menganalisis terhadap kelayakan fisik, kelayakan peraturan, kelayakan keuangan dan produktivitas yang maksimal.

\section{Analisis Kelayakan Fisik}

Kriteria memungkinkan secara fisik meliputi : (1) Bentuk tanah dan ukuran, (2) Topografi tanah (3) Lokasi tanah / Letak tanah (4) Sarana dan Prasarana / Aksesibilitas.

\section{Analisis Peraturan}

Dalam aspek legal ini terdapat dua hal yangdapat ditinjau, yaitu zoning dan peraturan bangunan (building code) meliputi Garis Sempadan Bangunan (GSB) 
Koefisien Dasar Bangunan (KDB), Koefisien Lantai Bangunan (KLB) dan Koefisien Daerah Hijau (KDH).

\section{Analisis Keuangan}

Adapun kriteria yang biasa digunakan untuk menentukan kelayakan suatu usaha adalah :

1. Payback Period (PP)

Adapun model perhitungan yang digunakan dalam menghitung PP adalah sebagai berikut :

$$
\mathrm{PP}=\frac{\text { Investasi }}{\text { Kas Bersih/Tahun }} \times 1 \text { Tahun }
$$

Untuk menilai apakah usaha layak diterima atau tidak dari segi PP, maka hasil perhitungan PP Sekarang lebih kecil dari umur investasi.

2. Average Rate of Return (ARR)

Average Rate of Return (ARR) merupakan cara mengukur rata-rata pengembalian bunga dengan cara membandingkan antara rata-rata laba sebelum pajak (EAT) dengan rata-rata investasi. Rumus untuk menghitung ARR sebagai berikut :

$$
\mathrm{ARR}=\frac{\text { Rata-rata EAT(average earning after tax })}{\text { Rata-rata investasi (average investment })}
$$

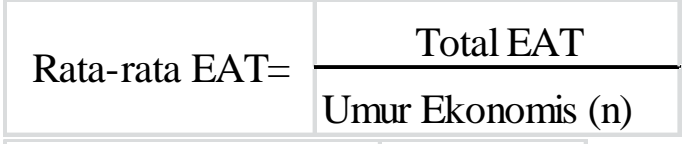

$$
\text { Rata-rata investasi }=\frac{\text { Investasi }}{2}
$$

\section{Net Present Value (NPV)}

Net Present Value (NPV) atau nilai bersih sekarang merupakan perbandingan antara PV kas bersih (PV of proceed) dan PV investasi (capital outlays) selama umur investasi. Selisih antara nilai kedua PV tersebutlah yang disebut dengan Net Present Value (NPV).Rumusan yang biasa digunakan dalam menghitung NPV adalah sebagai berikut :

$$
\mathrm{NPV}=\frac{\text { Kas bersih } 1}{(1+\mathrm{R})}+\frac{\text { Kas bersih } 2}{(1+\mathrm{R})^{2}}+\ldots \ldots+\frac{\text { Kas bersih N }}{(1+\mathrm{R})^{n}}-\text { Investasi }
$$

$\mathrm{R}=$ tingkat bunga pengembalian yang diinginkan (cost of capital)

NPV Positif, maka investasi diterima; dan jika

NPV Negatif, maka investasi ditolak;

4. Internal Rate or Return (IRR) ${ }^{\mathrm{n}}$

Internal Rate or Return (IRR) merupakan alat untuk mengukur tingkat pengembalian hasil intern. Cara mencari IRR dilakukan dengan menggunakan rumus sebagai berikut : 


$$
\text { IRR }=i_{1}+\frac{N P V_{1}}{N P V_{1-N P V_{1}}} X\left(i_{2}-i_{2}\right)
$$

Jika IRR lebih besar (>) dari bunga pinjaman, maka diterima

Jika IRR lebih kecil $(<)$ dari bunga pinjaman, maka ditolak

\section{Analisis Produktivitas yang maksimal (Maximally Productive)}

Sebuah properti atau alternatif properti dikatakan memiliki produktivitas yang maksimal bilamana memiliki tolok ukur finansial yang lebih baik dibanding properti atau alternatif properti lainnya. Tolok ukur finansial yang biasanya digunakan adalah Net Present Value (NPV), Internal Rate of Return (IRR), Payback Period (PP), Average Rate of Return (ARR). Bilamana dua atau lebih alternatif properti samasama menunjukkan hasil analisis layak secara fisik, diijinkan secara peraturan, dan layak secara keuangan, maka alternatif properti yang memenuhi kriteria HBU adalah alternatif properti yang memiliki tolok ukur finansial yang lebih baik dibanding alternatif properti lainnya.

\section{HASIL PENELITIAN DAN PEMBAHASAN}

\section{Analisis Penilaian Tanah}

Pendekatan penilaian yang digunakan untuk menentukan nilai tanah adalah dengan pendekatan data pasar. Berdasarkan analisis terhadap objek yang dinilai dengan mempertimbangkan data-data pembanding, terutama kesamaan fisik dan lokasi, tanggal transaksi dan faktor-faktor lainnya, maka nilai per $\mathrm{m}^{2}$ yang digunakan adalah Rp18.409.500,-. Maka nilai Pasar objek yang dinilai merupakan perkalian dari luas dengan nilai per $\mathrm{m}^{2}$ sehingga nilai objek tanah seluas $2.644 \mathrm{~m}^{2}$ adalah Rp48.674.718.000,-

Bentuk fisik tanah persegi panjang dengan lebar depan 30m, seluas $2.644 \mathrm{~m}^{2}$ sangat layak untuk mendirikan sebuah hotel, pusat perbelanjaan dan tempat parkir. Topografi tanah yang datar akan memudahkan pembangunan ketiga alternatif penggunaan atas tanah. Lokasi tanah yang berada di pinggir jalan akan sangat memudahkan akses, baik untuk kegunaan hotel, pusat perbelanjaan dan parkir kendaraan. Sarana dan Prasarana/Aksesbilitas disekitar objek sangat lengkap akan sangat mendukung penggunaan dari hotel, pusat perbelanjaan dan tempat parkir.

Peraturan-peraturan tentang bangunan yang berlaku di lokasi penelitian dibatasi dengan Koefisien Dasar Bangunan (KDB) paling tinggi 40\% dan Koefesien Dasar Hijau $(\mathrm{KDH})$ paling rendah 30\%. Bila dilihat dari alternatif bangunan didapat hasil sebagai berikut :

1) KDB bangunan hotel sebesar 23\%, Bangunan Pusat Perbelanjaan sebesar $38 \%$ dan Tempat Parkir sebesar 1\% yang berarti dibawah standar maximum yang ditentukan dalam peraturan yakni sebesar $40 \%$, maka ketiga bangunan tersebut layak untuk dibangun.

2) $\mathrm{KDH}$ bangunan hotel sebesar $77 \%$, Bangunan Pusat Perbelanjaan sebesar $62 \%$ dan Tempat Parkir sebesar 99\% yang berarti dibawah standar minimum yang 
ditentukan dalam peraturan yakni sebesar 30\%, maka ketiga bangunan tersebut layak untuk dibangun.

\section{Analisis Keuangan Hotel}

Hotel yang akan direncanakan untuk dibangunadalah hotel Bintang 2 . Beberapa hotel bintang 2 bertingkat 7 dengan jumlah kamar sebanyak 90 kamar, keluasan seluruh hotel seluas $4.200 \mathrm{~m}^{2}$. Tarif sewa kamar per harisebesar Rp340.000,dan fasilitas lainnya berupa ruang rapat 2 buah masing-masing ukuran $8 \times 15 \mathrm{~m}^{2}$. Nilai Investasi untuk rencana pembangunan hotel dan fasilitasnya adalah sebesar Rp36.761.648.000. Maka berdasarkan analisis di dapat hasil kelayakan keuangan usaha hotel seperti pada tabel dibawah ini :

Tabel 1. Kelayakan Keuangan Hotel

\begin{tabular}{|c|c|c|c|c|c|c|}
\hline Tahun & Pendapatan & Pengeluaran & EAT & Cash Flow & $\begin{array}{c}\text { Acumulated Cash } \\
\text { Flow } \\
\end{array}$ & PV \\
\hline 1 & 0 & 0 & 0 & 0 & 0 & $\underline{0}$ \\
\hline 2 & $4,168,350,000$ & $5,685,248,883$ & $(1,516,898,883)$ & $9,853,598,883$ & $9,853,598,883$ & $6,842,777,002$ \\
\hline 3 & $5,510,551,500$ & $6,106,087,424$ & $(595,535,924)$ & $11,616,638,924$ & $21,470,237,807$ & $6,722,591,970$ \\
\hline 4 & $6,929,533,575$ & $6,458,573,671$ & $353,219,928$ & $13,388,107,246$ & $34,858,345,054$ & $6,456,456,041$ \\
\hline 5 & $8,428,695,078$ & $6,829,764,595$ & $1,199,197,862$ & $15,258,459,673$ & $50,116,804,727$ & $6,132,032,726$ \\
\hline 6 & $9,383,029,296$ & $7,079,046,971$ & $1,727,986,744$ & $16,462,076,268$ & $66,578,880,994$ & $5,513,116,034$ \\
\hline 7 & $9,664,520,175$ & $7,177,630,740$ & $1,865,167,077$ & $16,842,150,915$ & $83,421,031,909$ & $4,700,3$ \\
\hline 8 & $9,954,455,780$ & $7,278,819,538$ & $2,006,727,182$ & $17,233,275,319$ & $100,654,307,228$ & $4,007,90$ \\
\hline 9 & $10,253,089,454$ & $7,382,684,468$ & $2,152,803,740$ & $17,635,773,922$ & $118,290,081,150$ & $3,417,931,136$ \\
\hline 10 & $10,560,682,138$ & $7,489,298,622$ & $2,303,537,637$ & $18,049,980,759$ & $136,340,061,909$ & $2,915,172,664$ \\
\hline 11 & $10,877,502,602$ & $7,598,737,142$ & $2,459,074,095$ & $18,476,239,744$ & $154,816,301,653$ & $2,486,67$ \\
\hline 12 & $11,203,827,680$ & $7,376,880,479$ & $2,870,210,400$ & $18,580,708,159$ & $173,397,009,812$ & $2,083,950,071$ \\
\hline 13 & $11,539,942,510$ & $7,492,201,650$ & $3,035,805,645$ & $19,032,144,160$ & $192,429,153,972$ & $1,778,818,019$ \\
\hline 14 & $11,886,140,785$ & $7,610,585,503$ & $3,206,666,462$ & $19,496,726,289$ & $211,925,880,261$ & $1,518,533,055$ \\
\hline 15 & $12,242,725,009$ & $7,732,115,979$ & $3,382,956,772$ & $19,974,840,988$ & $231,900,721,249$ & $1,296,476,473$ \\
\hline 16 & $12,610,006,759$ & $7,856,879,380$ & $3,564,845,535$ & $20,466,886,139$ & $252,367,607,388$ & $1,107,010,746$ \\
\hline 17 & $12,988,306,962$ & $7,984,964,432$ & $3,752,506,898$ & $20,973,271,394$ & $273,340,878,781$ & $945,333,381$ \\
\hline 18 & $13,377,956,171$ & $8,116,462,360$ & $3,946,120,358$ & $21,494,418,531$ & $294,835,297,312$ & $807,352,645$ \\
\hline 19 & $13,779,294,856$ & $8,251,466,958$ & $4,145,870,923$ & $22,030,761,814$ & $316,866,059,126$ & $689,581,879$ \\
\hline 20 & $14,192,673,702$ & $8,390,074,660$ & $4,351,949,281$ & $22,582,748,361$ & $339,448,807,488$ & $589,049,612$ \\
\hline 21 & $14,618,453,913$ & $8,532,384,618$ & $4,564,551,971$ & $23,150,838,531$ & $362,599,646,019$ & $503,223,089$ \\
\hline 22 & $15,057,007,530$ & $8,678,498,781$ & $4,783,881,562$ & $23,735,506,311$ & $386,335,152,330$ & $429,943,203$ \\
\hline 23 & $15,508,717,756$ & $8,828,521,973$ & $5,010,146,837$ & $24,337,239,729$ & $410,672,392,059$ & $367,369,131$ \\
\hline 24 & $15,973,979,289$ & $8,982,561,977$ & $5,243,562,984$ & $24,956,541,265$ & $435,628,933,324$ & $313,931,208$ \\
\hline 25 & $16,453,198,667$ & $9,140,729,619$ & $5,484,351,786$ & $25,593,928,286$ & $461,222,861,610$ & $268,290,811$ \\
\hline 26 & $16,946,794,627$ & $9,303,138,857$ & $5,732,741,827$ & $26,249,933,485$ & $487,472,795,095$ & $229,306,207$ \\
\hline 27 & $17,455,198,466$ & $9,469,906,872$ & $5,988,968,696$ & $26,925,105,338$ & $514,397,900,432$ & $196,003,473$ \\
\hline 28 & $17,978,854,420$ & $9,641,154,155$ & $6,253,275,199$ & $27,620,008,575$ & $542,017,909,008$ & $167,551,731$ \\
\hline 29 & $18,518,220,053$ & $9,817,004,610$ & $6,525,911,582$ & $28,335,224,663$ & $570,353,133,670$ & $143,242,049$ \\
\hline 30 & $19,073,766,654$ & $9,997,585,646$ & $6,807,135,756$ & $29,071,352,301$ & $599,424,485,971$ & $122,469,474$ \\
\hline
\end{tabular}

Penilaian kelayakan Hotel dilakukan dengan menghitung aliran kas selama 30 tahun, maka diperoleh Pay Back Period (PP) selama 4,04 tahun, Average Rate of Return (ARR) 18,24\%, Net Present Value (NPV) sebesar Rp25.990.789.993,- dan Internal Rate of Return (IRR) 29,47\%. 


\section{Analisis Keuangan Pusat Perbelanjaan}

Pusat perbelanjaan yang akan direncanakan untuk dibangunadalah berlantai 4 dengan menggunakan basement dengan ukuran basement $1.000 \mathrm{~m}^{2}$. Tarif sewa untuk pusat perbelanjaan ditetapkan rata-rata sebesar Rp175.000 per $\mathrm{m}^{2}$ (sudah termasuk service charge). Selain sumber pendapatan yang berasal dari sewa gedung sumber pendapatan lainnya adalah parkir kendaraan. Untuk tarif kendaraan ini kendaraan roda dua dikenakan tarif Rp2.000 dan kendaraan roda empat dikenakan tarif Rp3.000 pada jam pertama dan setiap satu jam berikutnya dikenai tambahan Rp1.000. Nilai Investasi untuk rencana pembangunan pusat perbelanjaan dan fasilitasnya adalah sebesar Rp24.457.981.317,-- Berdasarkan analisis di dapat hasil kelayakan keuangan usaha pusat perbelanjaan seperti pada tabel dibawah ini :

Tabel 2. Kelayakan Keuangan Pusat Perbelanjaan

\begin{tabular}{|c|c|c|c|c|c|c|}
\hline Tahun & Pendapatan & Pengeluaran & EAT & Cash Flow & $\begin{array}{c}\text { Acumulated Cash } \\
\text { Flow }\end{array}$ & PV \\
\hline 1 & 0 & 0 & 0 & 0 & 0 & 0 \\
\hline 2 & $2,712,500,000$ & $3,920,294,250$ & $(1,207,794,250)$ & $6,632,794,250$ & $6,632,794,250$ & $4,606,107,118$ \\
\hline 3 & $3,399,690,000$ & $4,036,821,000$ & $(477,848,250)$ & $7,436,511,000$ & $14,069,305,250$ & $4,303,536,458$ \\
\hline 4 & $4,133,054,100$ & $4,159,732,073$ & $(20,008,479)$ & $8,292,786,173$ & $22,362,091,423$ & $3,999,221,727$ \\
\hline 5 & $4,916,221,065$ & $4,289,493,314$ & $470,045,813$ & $9,205,714,379$ & $31,567,805,802$ & $3,699,570,143$ \\
\hline 6 & $5,753,291,187$ & $4,426,629,758$ & $994,996,072$ & $10,179,920,945$ & $41,747,726,747$ & $3,409,234,927$ \\
\hline 7 & $6,305,948,321$ & $4,528,864,632$ & $1,332,812,767$ & $10,834,812,953$ & $52,582,539,701$ & $3,023,797,446$ \\
\hline 8 & $6,476,848,505$ & $4,584,042,942$ & $1,419,604,172$ & $11,060,891,447$ & $63,643,431,148$ & $2,572,409,837$ \\
\hline 9 & $6,652,875,695$ & $4,640,538,443$ & $1,509,252,939$ & $11,293,414,138$ & $74,936,845,286$ & $2,188,739,320$ \\
\hline 10 & $6,834,183,700$ & $4,698,383,889$ & $1,601,849,859$ & $11,532,567,588$ & $86,469,412,874$ & $1,862,574,051$ \\
\hline 11 & $7,020,930,945$ & $4,757,612,878$ & $1,697,488,551$ & $11,778,543,823$ & $98,247,956,697$ & $1,585,250,488$ \\
\hline 12 & $7,304,671,936$ & $4,829,683,797$ & $1,856,241,104$ & $12,134,355,733$ & $110,382,312,430$ & $1,360,948,747$ \\
\hline 13 & $7,502,792,089$ & $4,891,784,177$ & $1,958,255,934$ & $12,394,576,266$ & $122,776,888,696$ & $1,158,445,176$ \\
\hline 14 & $7,706,855,846$ & $4,955,374,215$ & $2,063,611,223$ & $12,662,230,061$ & $135,439,118,757$ & $986,217,615$ \\
\hline 15 & $7,917,041,516$ & $5,020,491,133$ & $2,172,412,787$ & $12,937,532,649$ & $148,376,651,406$ & $839,716,657$ \\
\hline 16 & $8,133,532,756$ & $5,087,173,122$ & $2,284,769,725$ & $13,220,705,878$ & $161,597,357,284$ & $715,080,124$ \\
\hline 17 & $8,461,618,760$ & $5,168,596,868$ & $2,469,766,419$ & $13,630,215,629$ & $175,227,572,913$ & $614,358,036$ \\
\hline 18 & $8,691,294,317$ & $5,238,527,568$ & $2,589,575,061$ & $13,929,821,885$ & $189,157,394,798$ & $523,218,552$ \\
\hline 19 & $8,927,860,140$ & $5,310,143,977$ & $2,713,287,122$ & $14,238,004,117$ & $203,395,398,915$ & $445,661,830$ \\
\hline 20 & $9,171,522,938$ & $5,383,488,421$ & $2,841,025,888$ & $14,555,011,359$ & $217,950,410,274$ & $379,653,692$ \\
\hline 21 & $9,422,495,620$ & $5,458,604,332$ & $2,972,918,466$ & $14,881,099,952$ & $232,831,510,226$ & $323,466,170$ \\
\hline 22 & $9,801,862,514$ & $5,550,644,406$ & $3,188,413,580$ & $15,352,506,920$ & $248,184,017,146$ & $278,094,173$ \\
\hline 23 & $10,068,119,432$ & $5,629,438,118$ & $3,329,010,985$ & $15,697,557,550$ & $263,881,574,696$ & $236,953,662$ \\
\hline 24 & $10,342,364,058$ & $5,710,140,525$ & $3,474,167,649$ & $16,052,504,583$ & $279,934,079,279$ & $201,926,305$ \\
\hline 25 & $10,624,836,022$ & $5,792,799,786$ & $3,624,027,177$ & $16,417,635,808$ & $296,351,715,087$ & $172,099,444$ \\
\hline 26 & $10,915,782,146$ & $5,877,465,322$ & $3,778,737,618$ & $16,793,247,468$ & $313,144,962,555$ & $146,697,357$ \\
\hline 27 & $11,354,451,439$ & $5,981,562,200$ & $4,029,666,929$ & $17,336,013,639$ & $330,480,976,193$ & $126,198,908$ \\
\hline 28 & $11,663,116,181$ & $6,070,393,773$ & $4,194,541,806$ & $17,733,509,954$ & $348,214,486,147$ & $107,577,095$ \\
\hline 29 & $11,981,040,866$ & $6,161,387,809$ & $4,364,739,793$ & $18,142,428,674$ & $366,356,914,822$ & $91,714,772$ \\
\hline 30 & $12,308,503,291$ & $6,254,599,131$ & $4,540,428,120$ & $18,563,102,422$ & $384,920,017,244$ & $78,201,157$ \\
\hline
\end{tabular}

Penilaian kelayakan pusat perbelanjaan dilakukan dengan menghitung aliran kas selama 30 tahun terhadap usulan penggunaan pusat perbelanjaan maka diperoleh Pay Back Period (PP) selama 4,24 tahun, Average Rate of Return (ARR) 17,82\%, Net Present Value (NPV) sebesar Rp15.438.689.989,- dan Internal Rate of Return (IRR) $28,48 \%$.

\section{Hasil Kelayakan Keuangan Tempat Parkir}

Tempat parkir yang akan direncanakan untuk dibangun adalah menampung kendaraan yang melakukan aktifitas di sekitar Jalan Sam Ratulangi . Tarif parkir yang dikenakan untuk fasilitas parkir roda dua adalah sebesar Rp2.000 dan untuk 
kendaraan roda empat dikenakan tarif Rp3.000 pada jam pertama dan setiap satu jam berikutnya dikenai tambahan Rp1.000,- Nilai Investasi untuk rencana pembangunan tempat parkir dan fasilitasnya adalah sebesar Rp959.226.000,-. Berdasarkan analisis di dapat hasil kelayakan keuangan usaha tempat parkir pada table dibawah ini :

Tabel 3. Kelayakan Keuangan Tempat Parkir

\begin{tabular}{|c|c|c|c|c|c|c|}
\hline Tahun & Pendapatan & Pengeluaran & EAT & Cash Flow & $\begin{array}{c}\text { Acumulated Cash } \\
\text { Flow }\end{array}$ & PV \\
\hline 1 & 0 & 0 & 0 & 0 & 0 & 0 \\
\hline 2 & $328,500,000$ & $310,603,960$ & $13,422,030$ & $639,103,960$ & $639,103,960$ & $443,822,194$ \\
\hline 3 & $394,200,000$ & $320,419,460$ & $55,335,405$ & $714,619,460$ & $1,353,723,420$ & $413,552,928$ \\
\hline 4 & $473,040,000$ & $331,318,220$ & $106,291,335$ & $804,358,220$ & $2,158,081,640$ & $387,904,234$ \\
\hline 5 & $567,648,000$ & $343,499,295$ & $168,111,529$ & $911,147,295$ & $3,069,228,935$ & $366,169,663$ \\
\hline 6 & $681,177,600$ & $357,201,200$ & $242,982,300$ & $1,038,378,800$ & $4,107,607,735$ & $347,750,959$ \\
\hline 7 & $783,354,240$ & $370,155,376$ & $309,899,148$ & $1,153,509,616$ & $5,261,117,351$ & $321,923,364$ \\
\hline 8 & $783,354,240$ & $375,552,123$ & $305,851,588$ & $1,158,906,363$ & $6,420,023,715$ & $269,524,581$ \\
\hline 9 & $783,354,240$ & $381,056,805$ & $301,723,076$ & $1,164,411,045$ & $7,584,434,760$ & $225,670,661$ \\
\hline 10 & $783,354,240$ & $386,671,581$ & $297,511,994$ & $1,170,025,821$ & $8,754,460,581$ & $188,965,702$ \\
\hline 11 & $783,354,240$ & $392,398,652$ & $293,216,691$ & $1,175,752,892$ & $9,930,213,472$ & $158,242,213$ \\
\hline 12 & $900,857,376$ & $407,052,999$ & $370,353,282$ & $1,307,910,375$ & $11,238,123,848$ & $146,690,852$ \\
\hline 13 & $900,857,376$ & $413,011,444$ & $365,884,449$ & $1,313,868,820$ & $12,551,992,668$ & $122,799,276$ \\
\hline 14 & $900,857,376$ & $419,089,058$ & $361,326,239$ & $1,319,946,434$ & $13,871,939,102$ & $102,806,095$ \\
\hline 15 & $900,857,376$ & $425,288,224$ & $356,676,864$ & $1,326,145,600$ & $15,198,084,701$ & $86,074,105$ \\
\hline 16 & $900,857,376$ & $431,611,373$ & $351,934,502$ & $1,332,468,749$ & $16,530,553,450$ & $72,070,427$ \\
\hline 17 & $1,035,985,982$ & $448,195,631$ & $440,842,764$ & $1,484,181,613$ & $18,014,735,063$ & $66,896,880$ \\
\hline 18 & $1,035,985,982$ & $454,774,235$ & $435,908,811$ & $1,490,760,217$ & $19,505,495,281$ & $55,994,499$ \\
\hline 19 & $1,035,985,982$ & $461,484,412$ & $430,876,178$ & $1,497,470,394$ & $21,002,965,675$ & $46,872,117$ \\
\hline 20 & $1,035,985,982$ & $468,328,792$ & $425,742,893$ & $1,504,314,774$ & $22,507,280,449$ & $39,238,627$ \\
\hline 21 & $1,035,985,982$ & $475,310,059$ & $420,506,942$ & $1,511,296,042$ & $24,018,576,490$ & $32,850,605$ \\
\hline 22 & $1,191,383,880$ & $494,085,795$ & $522,973,564$ & $1,685,469,674$ & $25,704,046,165$ & $30,530,473$ \\
\hline 23 & $1,191,383,880$ & $501,349,105$ & $517,526,081$ & $1,692,732,985$ & $27,396,779,150$ & $25,551,700$ \\
\hline 24 & $1,191,383,880$ & $508,757,683$ & $511,969,648$ & $1,700,141,562$ & $29,096,920,712$ & $21,386,277$ \\
\hline 25 & $1,191,383,880$ & $516,314,431$ & $506,302,086$ & $1,707,698,311$ & $30,804,619,023$ & $17,901,112$ \\
\hline 26 & $1,191,383,880$ & $524,022,315$ & $500,521,174$ & $1,715,406,195$ & $32,520,025,217$ & $14,984,925$ \\
\hline 27 & $1,370,091,462$ & $545,287,425$ & $618,603,028$ & $1,915,378,886$ & $34,435,404,104$ & $13,943,155$ \\
\hline 28 & $1,370,091,462$ & $553,306,707$ & $612,588,566$ & $1,923,398,169$ & $36,358,802,272$ & $11,667,943$ \\
\hline 29 & $1,370,091,462$ & $561,486,375$ & $606,453,815$ & $1,931,577,836$ & $38,290,380,109$ & $9,764,636$ \\
\hline 30 & $1,370,091,462$ & $569,829,636$ & $600,196,370$ & $1,939,921,097$ & $40,230,301,206$ & $8,172,345$ \\
\hline
\end{tabular}

Penilaian kelayakan pusat perbelanjaan dilakukan dengan menghitung aliran kas selama 30 tahun terhadap usulan penggunaan tempat parkir, maka diperoleh Pay Back Period (PP) selama 2,45 tahun, Average Rate of Return (ARR) 76,81\%, Net Present Value (NPV) sebesar Rp3.090.496.551,- dan Internal Rate of Return (IRR) $53,85 \%$. Adapun hasil perhitungan terperinci dapat dilihat di dalam lampiran (lampiran 6).

\section{KESIMPULAN}

1. Nilai Wajar Tanah milik pemerintah Kota Manado yang berada di Jalan Sam Ratulangi Nomor 87 Manado adalah sebesar Rp48.674.718.000,--.

2. Nilai investasi untuk penggunaan hotel adalah sebesar Rp36.761.648.000, untuk pusat perbelanjaan sebesar Rp24.597.981.000,- dan untuk tempat parkir sebesar Rp959.226.000,- 
3. Hasil analis Penggunaan Tertinggi dan Terbaik adalah sebagai berikut:

\begin{tabular}{|l|l|l|l|l|l|}
\hline No. & $\begin{array}{c}\text { Aternatif } \\
\text { Penggunaan }\end{array}$ & $\begin{array}{l}\text { Kelayakan } \\
\text { Fisik }\end{array}$ & $\begin{array}{l}\text { Kelayakan } \\
\text { Peraturan }\end{array}$ & $\begin{array}{l}\text { Kelayakan } \\
\text { Keuangan }\end{array}$ & $\begin{array}{l}\text { Produksi } \\
\text { yang } \\
\text { maksimal }\end{array}$ \\
\hline 1. & Hotel & Layak & Layak & Layak & $\begin{array}{l}\text { Tidak } \\
\text { Maksimal }\end{array}$ \\
\hline 2. & $\begin{array}{l}\text { Pusat } \\
\text { Perbelanjaan }\end{array}$ & Layak & Layak & Layak & $\begin{array}{l}\text { Tidak } \\
\text { Maksimal }\end{array}$ \\
\hline 3. & Tempat Parkir & Layak & Layak & Layak & Maksimal \\
\hline
\end{tabular}

4. Berdasarkan analisis kelayakan fisik, peraturan, keuangan dan produktifitas yang maksimal, dapat disimpulkan bahwa usulan penggunaan sebagai tempat parkir merupakan penggunaan tertinggi dan terbaik yaitu jangka waktu pengembalian investasi $(P P)$ selama 2,45 tahun, tingkat pengembalian bunga (ARR) sebesar $76,81 \%$ dan tingkat pengembalian yang tinggi (IRR) yaitu sebesar 53,85\%.

\section{SARAN}

1. Analisis penggunaan tertinggi dan terbaik ini dilakukan pada saat sekarang dan disarankan apabila Pemerintah Kota Manado akan melakukan kerjasama dengan pihak ketiga seperti kerjasama pemanfaaatan dengan selayaknya dilakukan penilaian ulang karena nilai dapat berubah setiap waktu.

2. Dengan nilai aset yang cukup tinggi dan letaknya yang sangat strategis diminta kepada pemerintah daerah untuk segera memaksimalkan aset tersebut sehingga keberadaan aset tersebut dapat menjadi nilai tambah baik kepada pemerintah Kota Manado maupun kepada investor jika terdapat investor yang akan berinvestasi di Kota Manado.

\section{DAFTAR PUSTAKA}

Akmaluddin dan Christiono Utomo. 2013, Analisis Highest and Best Use (HBU) pada Lahan Jl. Gubeng Raya No. 54 Surabaya, Jurnal Teknik Pomits Vol.2 No.1, Istitut Teknologi Sepuluh Nopember (ITS), Surabaya.

Bidaruni Anggarawati dan Christiono Utomo. 2013, Analisis Penggunaan Lahan Kawasan Komersil Perumahan CitraRaya Surabaya dengan Metode Highest and Best Use, Jurnal Teknik Pomits Vol.2 No.2, Istitut Teknologi Sepuluh Nopember (ITS), Surabaya.

Badan Pusat Statistik Manado, 2016. Manado Dalam Angka 2016, Katalog BPS:1102001.7171,Manado.

Badan Pusat Statistik Manado, 2015. Manado Dalam Angka 2015, Katalog BPS : 1102001.7171,Manado.

Badan Pusat Statistik Manado,2016. Berita Resmi Statistik, Perkembangan IHK/Inflasi Kota Manado, No. 27/05/71/Th.X, Manado.

Grissom.1990, Highest and Best Use : The Evolving Paradigm, The Journal of Estate Research, Vol. 5, Number 1, United Kingdom. 
Hargraves. 1990.The Evolution of Highest and Best Use, The New Zealand Valuers' Journal1990, hal.27-29, Wellington.

Hidayati, Harjanto. 2016, Konsep Dasar Penilaian Properti (edisi Kedua), BPFEYogyakarta.

Internasional Acconting Standars Boards, 2008, Highest dan Best Use (Agenda Paper 3A), United Kingdom.

Jakfar, Kasmir. 2012, Study Kelayakan Bisnis (edisi revisi), Kencana, Jakarta.

Komite Penyusun SPI. 2015, Standar Penilaian Indonesia, MAPPI, Jakarta.

Lesman Ertri, 2014. Analisis Highest and Best Use Terhadap Aset Tetap Milik Pemerintah Kabupaten Banyumas (Studi Kasus Lahan di Jalan Dr. Angka, Purwokerto), Tesis, Program Pasca Sarjana Universita Gajah Mada, Yogyakarta.

Miftahul Mubayyinah dan Christiono Utomo. 2012, Analisis Highest and Best Use (HBU) Lahan "X" Untuk Properti Komersial, Jurnal Teknik Vol.1 No.1, Istitut Teknologi Sepuluh Nopember (ITS), Surabaya.

Menteri Dalam Negeri, 2016. Peraturan Menteri Dalam Negeri Nomor 19 Tahun 2016 tentang Pedoman Teknis Pengelolaan Barang Milik Daerah, Kementerian Dalam Negeri Jakarta.

Minura. 2015, Manajemen Aset Tanah Milik Pemerintah Kabupaten Kuantan Singingi Tahun 2009-2013, Jurnal FISIP Vol.2 No.1, Iniversitas Riau, Pekanbaru.

Mooya, Manya M, 2016.Real Estate Valuation Theory, Springer, Berlin.

Novasari Arlidika, 2015. Analisis Penggunaan Tertinggi dan Terbail Pada Tanah Kosong Milik Pemerintah Provinsi D.I. Yogyakakarta (Studi Tanah di Jalan Jogja - Wates Km. 5.5 Desa Ambarketawang, Gamping), Tesis, Program Pasca Sarjana Universita Gajah Mada, Yogyakarta.

Putra Ibnu Aswiar, 2014. Optimalisasi Pemanfaatan Lahan melalui Penggunaan Tertinggi dan Terbaik Terhadap Lahan Kosong di Komplek Cunda Plaza Lhokseumawe, Provinsi Aceh, Tesis, Program Pasca Sarjana Universita Gajah Mada, Yogyakarta.

Putu Dharma Warsika, 2009, Studi Kelayakan Investasi Bisnis Properti (Studi Kasus : Ciater Riung Rangga), Jurnal Ilmiah Teknik Sipil Vol.13 No.1, Universitas Udayana, Denpasar.

Pemerintah Republik Indonesia, 2015. Undang-Undang Nomor 2 Tahun 2015 yaitu Penetapan Peraturan Pemerintah Pengganti Undang-Undang Nomor 2 Tahun 2014 tentang Perubahan Atas Undang-Undang Nomor 23 Tahun 2014 tentang Pemerintahan Daerah Menjadi Undang-Undang, Jakarta.

Pemerintah Republik Indonesia, 2009. Undang-undang Nomor 28 Tahun 2009 tentang Pajak Daerah dan Retribusi Daerah, Jakarta.

Pemerintah Republik Indonesia, 2010. Peraturan Pemerintah Nomor 71 Tahun 2010 tentang Standar Akutansi Pemerintahan.

Pemerintah Republik Indonesia, 2014. Peraturan Pemerintah Nomor 27 Tahun 2014 tentang Pengelolaan Barang Milik Negara/Daerah, Jakarta. 
Riza, 2014. Optimalisasi Aset Tanah Bekas Gedung Bioskop Pemerintah Kabupaten Bireuen dengan Menggunakan Analisis Highest and Best Use (HBU), Tesis, Program Pasca Sarjana Universita Gajah Mada, Yogyakarta.

Siregar, Doli, 2004.Manajemen Aset, Gramedia Pustaka Utama, IKPI, Jakarta. 